\title{
John J. Mearsheimer: an offensive realist between geopolitics and power
}

\author{
Peter Toft \\ Department of Political Science, University of Copenhagen, Østerfarimagsgade 5, DK 1019 \\ Copenhagen K, Denmark. \\ E-mail: pt@ifs.ku.dk
}

\begin{abstract}
With a number of controversial publications behind him and not least his book, The Tragedy of Great Power Politics, John J. Mearsheimer has firmly established himself as one of the leading contributors to the realist tradition in the study of international relations since Kenneth Waltz's Theory of International Politics. Mearsheimer's main innovation is his theory of 'offensive realism' that seeks to re-formulate Kenneth Waltz's structural realist theory to explain from a structural point of departure the sheer amount of international aggression, which may be hard to reconcile with Waltz's more defensive realism. In this article, I focus on whether Mearsheimer succeeds in this endeavour. I argue that, despite certain weaknesses, Mearsheimer's theoretical and empirical work represents an important addition to Waltz's theory. Mearsheimer's work is remarkably clear and consistent and provides compelling answers to why, tragically, aggressive state strategies are a rational answer to life in the international system. Furthermore, Mearsheimer makes important additions to structural alliance theory and offers new important insights into the role of power and geography in world politics.
\end{abstract}

Journal of International Relations and Development (2005) 8, 381-408. doi:10.1057/palgrave.jird.1800065

Keywords: great power politics; international security; John J. Mearsheimer; offensive realism; realism; security studies

\section{Introduction}

Dangerous security competition will inevitably re-emerge in post-Cold War Europe and Asia. ${ }^{1}$ International institutions cannot produce peace. Germany and Japan are likely to pursue nuclear deterrents. America is likely to end its continental commitments in Europe and Asia. The United States (US) should curb China's rise. All great powers act as aggressive powermaximizers despite embracing liberal democracy. America was wrong to invade Iraq and Afghanistan. These statements roughly sum up the

Journal of International Relations and Development, 2005, 8, (381-408) ～www.palgrave-journals.com/jird (C) 2005 Palgrave Macmillan Ltd 1408-6980/05 \$30.00 
conclusions suggested by John Mearsheimer in his numerous articles and books covering a range of subjects on international relations. The provocative nature of Mearsheimer's work has spurred several major debates both within the sub-discipline of international relations (IR) and beyond academia. ${ }^{2}$ As a consequence of this remarkable ability to inspire important debates, Mearsheimer stands out as one on the most controversial and influential contributors to the contemporary realist tradition. In his earlier writings, Mearsheimer was primarily concerned with strategic studies and produced a number of articles and books on military strategy (Mearsheimer 1983, 1984, 1988, 1989). However, the underpinnings of his most debated arguments are his particular version of structural realism, dubbed 'offensive realism', which is fully developed in the book, The Tragedy of Great Power Politics (Mearsheimer 2001c) - although his theoretical argument is present in earlier works as well (e.g. Mearsheimer 1988: 225, 1995a, b, 1998, 2001b).

In this article, I deal with Mearsheimer's theoretical work with the purpose of appraising his specific contribution to the structural realist strand within the broad realist tradition in the study of international relations. ${ }^{3}$ This is an important task for two main reasons. First, the accumulation of knowledge is probably the most celebrated scientific ideal and Mearsheimer explicitly builds on and seeks to improve the insights of Kenneth Waltz's structural realism (neorealism) with its focus on the effects of the international anarchic structure. Consequently, it is highly important to evaluate whether Mearsheimer succeeds in this endeavour. Second, Mearsheimer has used his work as a platform for launching strong criticisms against both competing IR theories and as a vehicle for devising foreign policy prescriptions. And because the process of making national security policy is affected by the ideas and theories that shape the central debates of the day, it is important to survey the quality of Mearsheimer's analyses as some theories obviously provide better answers than others, and some are prescriptions for disaster. Consequently, I ask the following central question: To what degree has John Mearsheimer improved our understanding of the effects of the international structure upon the workings of world politics?

The remainder of this article is organized as follows: I begin with a presentation of offensive realism, outline its dynamics, and position Mearsheimer's theoretical argument in the context of the realist tradition. In the main body of the article, I discuss the thrust of Mearsheimer's analyses and scrutinize his considerations on contemporary world politics and US foreign policy. Finally, I conclude by answering the central question of the article in the affirmative, arguing that despite certain blemishes Mearsheimer's work constitutes an important extension of structural realism and to our understanding of the role of the anarchic structure of international politics. 


\section{Offensive Realism}

The aim of Mearsheimer's theory is to explain why relations between the great powers of the modern state system are fraught with conflict. Echoing Kenneth Waltz (1979), Mearsheimer argues that the structure of international politics is key in understanding this state of affairs. Specifically, Mearsheimer relies on five core assumptions - shared more or less by most contemporary realists, ${ }^{4}$ which characterize the essential traits of international politics. First, international politics is played out in an anarchical realm meaning that there is no 'government of governments' to enforce rules and punish perpetrators. Second, no state can ever be absolutely sure of each other's intentions nor be sure that other states will not use force against them. Furthermore, states suffer from imperfect information about each other's intentions and intentions are in constant flux - benign intentions can quickly change into malignant ones and vice versa. Third, survival is the primary motivation of all states in the international system. Survival must have top priority since the autonomy of the state is a prerequisite for the achievement of all other ends. Fourth, states are rational entities in the instrumental sense of the word, that is, they think strategically about their external situation and choose the strategy that seems to maximize their basic aim of survival. Finally, Mearsheimer (1995b, 2001c) states always possess some military capacity enabling them to hurt and possibly to destroy each other. Marrying together these assumptions, Mearsheimer infers that the states soon realize that the most efficient way to guarantee survival in anarchy is to maximize their relative power with the ultimate aim of becoming the strongest power - that is, a hegemon. However, not all states can maximize their relative power simultaneously and, therefore, the state system is destined to be an arena of relentless security competition as long as it remains anarchic (Mearsheimer 2001c: Chapter 2).

\section{The pursuit of power}

Evidently, power plays a key role in Mearsheimer's thinking. Like most contemporary realists he follows Waltz (1979: 191) and equates power not with outcomes but with material capabilities (Mearsheimer 2001c: 57-61), arguing that outcomes are a poor predictor of the balance of power since weak states may sometimes defeat their stronger opponents (2001c: 57). Unfortunately, measuring capabilities reliably is difficult and realists have hotly debated this issue. In The Tragedy of Great Power Politics, Mearsheimer contributes to the realist power debate by going to great lengths to clarify his views on the subject. Dividing state capabilities into latent (economy and population) and actual power (military), Mearsheimer argues that military power is most important when analysing world politics because it is the ultimo ratio of 
international politics' (2001c: 56). Furthermore, he argues that land power is crucial because land armies are necessary to control territory - the most important asset in a world of territorial states (2001c: Chapter 4). Mearsheimer's preoccupation with military power and especially with land power owes to insights developed in his earlier writings on deterrence and military strategy (Mearsheimer 1983, 1984, 1988, 1989), and is a noteworthy contribution to the realist power debate as his arguments are both logical and convincing. The downside of this extreme focus on military capabilities is, however, that Mearsheimer's analyses are blind to other ways of exercising power - for example, economic warfare. In addition, other realists have shown that states are highly concerned with trends in latent power rather than with actual military capabilities (e.g. Copeland 2000). Thus, the French and British fears of a disarmed Germany in the 1920s are difficult to reconcile with Mearsheimer's argument. Furthermore, the focus on land power leads Mearsheimer to focus narrowly on territorial expansion. This implies a risk that his analyses miss a host of other ways of gaining and exercising influence. Moreover, Mearsheimer himself recognizes that territorial conquest is unlikely to be the prevalent way of power maximization in the decades to come as he expects China - the most likely challenger to the US - to attempt to dominate Asia in more subtle ways (Brzezinski and Mearsheimer 2005).

\section{How states get power}

In Mearsheimer's view, maximizing relative power to the point of hegemony is the ultimate aim of every state. A hegemon is defined 'as a state that is so powerful that it dominates all the other states in the system' (Mearsheimer 1995a: 86, 2001c: 40, footnote 15). This concept is applied both globally and regionally. To cite Mearsheimer: 'Hegemony means domination of the system, which is usually interpreted as the entire world ... [but] it is possible to apply the concept of a system more narrowly and use it to describe particular regions, such as Europe, North-East Asia and the Western Hemisphere' (1995a: 80, footnote 4). Global hegemony, however, is virtually impossible because projecting massive force across the world's oceans is, according to Mearsheimer, too difficult. Only in the rare case that a state attains a nuclear monopoly is global hegemony within reach. However, this is unlikely to happen 'because rival states will go to great lengths to develop nuclear retaliatory forces of their own' (Mearsheimer 2001c: 146). Thus, regional hegemony is the principal strategic state aim and, thus, the regional level takes centre stage in Mearsheimer's thinking. However, how do states attain hegemony? Mearsheimer distills two overall strategies. The first type involves direct attempts to gain relative power, while the second type is indirect and aims to check other aggressors from making gains. 
War is the principal way of gaining power. Even though it is costly, Mearsheimer (2001c: 147-152) argues that rational states may choose war if the benefits outweigh the costs. Most importantly, a successful war might oust a rival thereby making the aggressor safer. Short of war, blackmail offers another option to make relative gains by threatening a rival to make concessions. Blackmail is, however, only effective against minor states as major states are able to resist. Finally, states may gain power by way of baitand-bleed and bloodletting strategies - that is, by keeping or tricking rivals into protracted conflicts enabling the first state to get relatively stronger on the sidelines while the others fight. This is, however, difficult to do and the first state risks being exposed or confronting a winning rival alone should it unexpectedly prevail (Mearsheimer 2001c: 152-153) (Tables 1-3).

Balancing represents the most important way of checking aggression by deterring or fighting a potential aggressor through internal build-up and/or via alliance formation. In tune with most realist alliance literature, Mearsheimer argues that alliances are attractive because the burden of handling an aggressor is shared. However, alliances are also slow to form and tend to be inefficient because of collective action problems (Mearsheimer 2001c: 156-157). The drawbacks of alliances make buck-passing alluring. Buck-passing implies passing on the burden of handling an aggressor to someone else, hoping that

Table 1 State strategies

\begin{tabular}{ll}
\hline $\begin{array}{l}\text { Strategies for gaining power } \\
\text { War }\end{array}$ & May be efficient but costly \\
Blackmail & Cost efficient but ineffective against great powers \\
Bait-and-bleed & Cost efficient but difficult to bait rivals into conflict \\
Bloodletting & Cost efficient but risk of exposure \\
& \\
$\begin{array}{l}\text { Strategies for checking } \\
\text { Balancing }\end{array}$ & Efficient but costly, formation slow, hampered by coll. action problems \\
Buck-passing & Cost efficient but risky if the buck-catcher fails or succeeds too well \\
\hline
\end{tabular}

Table 2 Choosing between strategies of gaining power

\begin{tabular}{lll}
\hline Bipolarity & Balanced multipolarity & Unbalanced multipolarity \\
\hline Bloodletting & Limited war & Hegemonic war \\
Bait-and-bleed & Blackmail & (Nuclear blackmail) \\
& Bloodletting & \\
& Bait-and-bleed & \\
\hline
\end{tabular}


Table 3 Choosing between strategies of checking aggression

\begin{tabular}{llll}
\hline Distribution of power & \multicolumn{3}{c}{ Geographic Location } \\
\cline { 2 - 4 } & $\begin{array}{l}\text { Nearby landlocked } \\
\text { great powers }\end{array}$ & $\begin{array}{l}\text { Distant landlocked } \\
\text { great powers }\end{array}$ & $\begin{array}{l}\text { Off-shore } \\
\text { great powers }\end{array}$ \\
\hline Balanced multipolarity & Balancing & Buck-passing & Buck-passing \\
Unbalanced multipolarity & Balancing & Balancing & Balancing \\
Bipolarity & Balancing & Balancing & Balancing \\
\hline
\end{tabular}

they will be able to check the aggressor. Passing the buck is appealing because if conflict should break out, the buck-passer may sit safely on the bench, while the balance of power hopefully shifts to its advantage. As such, buck-passing implies a strong offensive element. Buck-passing is also risky, however, because the eventual buck-catcher may be defeated and leave the buck-passer alone to confront the aggressor. Conversely, if the buck-catcher successfully stops the aggressor, it may end up stronger and upset the balance of power to the disadvantage of the buck-passer (Mearsheimer 2001c: 157-162). Interestingly, Mearsheimer (2001c: 162-163) denounces bandwagoning as a way of handling an aggressor. Bandwagoning occurs when a state allies with a more powerful opponent. Arguably, bandwagoning is a common way to handle a threat and this strategy may also be a useful way to handle other strong opponents since by attaching itself to a stronger ally the bandwagoner will get a share of the spoils of victory and become stronger vis-à-vis a wider circle of states (Schweller 1998). Mearsheimer, however, denounces bandwagoning on theoretical grounds arguing that it violates balance-of-power logic since bandwagoning entails concessions to the more powerful. For this reason, it is a strategy of the extremely weak to be avoided.

\section{Choosing between strategies}

By outlining these very specific strategies, Mearsheimer is capable of deducing comparatively fine-grained hypotheses about great power behaviour. In order to predict when the different strategies are most likely, he operates with two explanatory variables: the distribution of relative power and geographic location (Taliaferro 2001), while other potential variables such as domestic politics or the balance between offence and defence, are left largely undebated, although explored extensively by other realist writers (e.g. Walt 1990; Van Evera 1999).

The most important variable that prompts either a strategy of gaining power or a strategy of checking aggression is the regional distribution of military 
power. Although states, according to Mearsheimer, always strive to maximize their relative power, they rationally calculate the cost and benefits of aggression taking into account the strength and likely actions of their competitors. Only when the benefits outweigh the costs do they go after additional increments of relative power (Mearsheimer 2001c: 38). Hence, when the balance of power is heavily skewed in favour of a great power, it is likely to wage a hegemonic war. Mearsheimer terms this state of affairs 'unbalanced multipolarity'. ${ }^{5}$ In unbalanced multipolarity, a strategy of hegemonic war is the best option seen from the perspective of a potential hegemon because a run for hegemony at that point has the best chances of succeeding despite the likely balancing efforts of other powers. Unfortunately, Mearsheimer makes no attempt to clarify more precisely under which conditions we should expect hegemonic war to result or whether the other methods of gaining power will be chosen. However, a closer examination makes clear that under some conditions the lesser methods of gaining power are logically more likely than others.

Following the logic of Mearsheimer's thinking, none of the two great powers in bipolarity are able to establish global hegemony because of the roughly equal distribution of world power. In bipolarity, waging a hegemonic war is irrational since the other great power possesses the wherewithal to defend itself and thwart the hegemonic aspirations of the other. Equally, blackmailing seems ineffective since the main opponent is capable of and likely to support the target state, thereby thwarting the blackmailer. Hence, the two protagonists are likely to work to weaken each other more indirectly by using bloodletting and bait-and-bleed strategies - for example, through a costly arms race or luring each other into prolonged struggles with minor powers. In balanced multipolarity, the room for manoeuvre is wider since there are more interacting players present with diverse-specific interests. This makes a strategy of 'limited' war against minor powers or an individual great power possible. Furthermore, a great power can more easily isolate and blackmail minor states, whereas the potential for successful bloodletting and bait-and-bleed methods also increases compared to bipolarity. However, in the final analysis Mearsheimer is quite unclear on this point. In contrast, Copeland's more dynamic neorealist argument about major war (2000) directly challenges Mearsheimer's argument since it specifies much more clearly when a great power is likely to choose hardline policies - that is, when it is confronted with deep and inevitable decline not a rise in its relative power (Copeland 2000: 37-42)

The distribution of power also conditions when states choose to check aggression. Contrary to his discussion of the methods of gaining power, Mearsheimer carefully points out when the powers opt for balancing or buckpassing.

In bipolarity, buck-passing is precluded because no third power exists to catch the buck. Balancing is, therefore, the only way of checking the ambitions 
of the other great power. In balanced multipolarity, on the other hand, buckpassing is more likely because each power can be confident that aggression can be checked by another great power. Whether a specific state chooses to pass the buck or balance, however, depends on the second explanatory variable of the theory - that is, its geographical location. The closer a great power is to a rival the more likely it is to balance because it would be first in line should the other choose to attack. Conversely, natural barriers or buffer states separating a specific great power from its rivals make buck-passing more likely. Mearsheimer argues that this is especially true of offshore powers because of the logistical problems of projecting sufficient military force across large bodies of water. In unbalanced multipolarity, however, the balance of power is so asymmetrically distributed in favour of one of the great powers that it has a fair chance of becoming a regional hegemon. When this situation occurs, balancing is the only rational response among the other great powers, assuming that they wish to preserve their autonomy (Mearsheimer 1998, 2001c: Chapter 8).

\section{Mearsheimer and the realist tradition}

Mearsheimer's emphasis on the structure of international politics and the resulting security dilemma as the key explanatory factor follows Kenneth Waltz's seminal neorealist theory (1979) and firmly places Mearsheimer within the 'tragedy' school of the realist tradition (cf. Spirtas 1996). However, the gloomy nature of his conclusions and the depiction of the international system as an arena of relentless competition for power clearly distinguish his approach from Waltz's more benign version. Rather, the nature of Mearsheimer's pessimistic analysis resembles more closely the 'evil school' (cf. Spirtas 1996) writings of figures such as Reinholdt Niebuhr (1932/2001), E.H. Carr (1946/ 1974), George Kennan (1946) Hans Morgenthau (1948/1985) and Henry Kissinger (1964).

Mearsheimer also departs from Waltzian neorealism in another important respect by including an intermediary variable at the unit-level, that is, state location, into his theory of offensive realism. By doing so, he makes a clear break with Waltz's purely structural theory in which the international distribution of power capabilities is the only variable of consequence (1979). ${ }^{6}$ The inclusion of geopolitics, however, is far from alien to the broader realist tradition. In fact, geopolitics has been present in realist thought for centuries (Haslam 2002: Chapter 4) and geography also plays a prominent role in recent, so-called post-classical realist contributions that in addition to the international power structure take into account the effects of non-structural systemic variables (Brooks 1997; Taliaferro 2001). ${ }^{7}$ 
By including state location in addition to the distribution of power, Mearsheimer also defies Waltz's curious analytical demarcation between theories of international politics and theories of foreign policy (Schmidt 2004: 429-430). Mearsheimer's theory explicitly tells us both something about aggregate international outcomes - for example, the frequency of wars and patterns of alliance formation - while at the same time it also provides us with explanations of individual state behaviour. This contrasts Waltz's extremely sceptical position concerning the possibility of theorizing about foreign policy because of the complex nature of variables at the unit-level and his firm rejection that his own structural theory has much to say about foreign policy at all (Waltz 1979: 70-71, 73-74, 1996). ${ }^{8}$ By explicitly taking structural realism into the sphere of foreign policy, Mearsheimer's offensive realism, thus, moves away from his otherwise Waltzian point of departure and towards a body of recent realist theories of foreign policy - the so-called neoclassical realism (Rose 1998; Schweller 2003).

In essence, however, structure does most of the explaining in Mearsheimers' theoretical universe and his theorizing stays firmly within the structural realist mould. For instance, whereas the 'evil school' realists identified the causes of international power struggles within the corrupt nature of man or within the nature of 'bad' states, Mearsheimer, like Waltz, insists that causes at the structural level rather than the unit-level are the primary key to understanding world politics. Moreover, although location plays an important role in Mearsheimer's thinking this variable is wholly subordinate to the structural balance of power variable since different power constellations determine the impact of location on state behaviour. For instance, in Mearsheimer's theory geography tells us when and which states are likely to balance or buck-pass. However, it does not affect the basic structural incentives to maximize relative power. This represents a distinct difference between Mearsheimer's thinking and the recent writings of neoclassical and post-classical realists who tend to relegate independent effects to non-structural variables. ${ }^{9}$

Thus, although Mearsheimer straddles insights from different strands within the broader realist tradition, he ultimately devotes primary importance to the effects of the international structure.

\section{Duelling structural realisms}

This brings us back to the most consequential hallmark of Mearsheimer's theoretical position. From basically an identical set of core assumptions as Mearsheimer, Waltz (Snyder 2002) concluded that the anarchic structure of world politics propels states not to maximize their share of world power, but rather to be first and foremost concerned with preventing relative losses - in the words of Joseph Grieco (1993), states act as defensive positionalists. 
Mearsheimer, however, reaches the opposite conclusion arguing that anarchy propels states to maximize relative power. This disagreement is essentially what has been dubbed the debate between offensive and defensive realists - the latter pertaining to Waltz's version and the former to Mearsheimer's - and it cuts across the other contemporary positions within realism (Labs 1997; Zakaria 1998; Jervis 1999; Donnelly 2000; Wivel 2000; Taliaferro 2001). ${ }^{10}$

Some scholars have argued that the disagreement is rooted in the fact that the two structural realisms make different assumptions about state motivation. Defensive realism allegedly assumes that states are only interested in maximizing their security, while offensive realists hold that states are rather inclined to maximize their relative power (Donnelly 2000: 63-64; Taliaferro 2001; Schmidt 2004: 434). This argument, however, is incorrect since both versions of structural realism start from the same basic assumptions: namely, that states are motivated by a desire to survive in form.

Arguably, the debate between structural offensive and defensive realism is not about motivating assumptions, but rather about how states living in a condition of anarchy best ensure their survival. Waltz holds that states behave more benignly than does Mearsheimer in that he strongly emphasizes the propensity of states to balance vigorously against whichever state becomes most powerful in the international anarchic system. The balancing dynamic, in turn, makes power-maximizing futile since such behaviour risks triggering a countervailing coalition that may ultimately jeopardize the very survival of the maximizing state. Contrary to Waltz, Mearsheimer (2001c: 34-35) assigns much less weight to the effectiveness of balancing, charging against Waltz that states cannot know when they have enough power to be secure. For this reason, the uncertainties arising from life in anarchy push states to seize every opportunity they can to maximize their power - albeit at a reasonable cost, since states are not 'mindless aggressors' (2001c: 37). Thus, at bottom we should not expect major differences between the behaviour of Waltz's defensive positionalist states and Mearsheimer's power-maximizing ones, and Mearsheimer (2001c: 37 ) readily concedes that even power-maximizing states need to check aggressors. Nevertheless, Mearsheimer, importantly, points to the fact that cost-sensitive states are loath to bear the costs of balancing and strongly inclined to buck-pass, a problem Waltz seems to disregard. ${ }^{11}$ Thus, in essence, the disagreement between Mearsheimer and Waltz is about the effectiveness of the balancing dynamic. If balancing often fails, then states are arguably better off maximizing power rather than relying solely on balancing and Mearsheimer may have a better solution than Waltz to the old realist schism of whether states are revisionists or status quo oriented, without having to rely on exogenous preference structures like the old 'evil school' realists. In the next section, I shall examine whether Mearsheimer's argument is logically sound and empirically solid. 


\section{The Power of Mearsheimer's Contribution}

Having discussed the core tenets of Mearsheimer's theoretical thinking above, the purpose of this section is to evaluate the thrust of his analyses. In order to do so, I pose two questions: (1) Is Mearsheimer's theoretical thinking logically compelling? and (2) How much of the history of international politics can be explained by his theory?

\section{The logic}

Figuring out whether the underpinning logic in Mearsheimer's theoretical thinking is compelling is important because a logically flawed theory also generates flawed explanatory hypotheses (Walt 1999: 12-13). At first glance, Mearsheimer's theory seems to have no obvious logical flaws. The argument that states maximize their power to ensure their survival in an anarchic and dangerous world is both convincingly and logically delineated. Furthermore, Mearsheimer communicates in a clearcut and easily understandable style, thereby adding to the impression of a sound logic. However, a closer look reveals four problems of logic.

The first problem concerns whether the hypotheses deduced from the theory flow logically from the assumptions. From his five basic assumptions, Mearsheimer infers that states live in a high-risk environment in which they are propelled to maximize their relative power because this is the best way to ensure their survival. However, starting from the same set of assumptions, defensive structural realists, as discussed above, reach the opposite conclusion: namely, that states are content with an international position far short of hegemony. What accounts for this discrepancy? As mentioned above, an important part of the problem is that Waltz and Mearsheimer reach different conclusions because they give different weight to the propensity of states to balance. The fact that both views are inferred from the same assumptions about state motivation, however, demonstrates that from a purely structural outset it is only possible to predict state behaviour in extremely general terms (cf. Brooks 1997). Waltz seems to be aware of this, arguing in vague terms that states seek power in order to survive from a minimum to world domination (Waltz 1979: 118). However, to argue that states always strive for maximum power is hard to reconcile with Mearsheimer's sparse assumptions. Even though balancing may sometimes fail, it is possible to infer only that states strive to acquire an adequate level of relative power - not that they always strive for more. To make his inferences fully consistent with his assumptions, therefore, Mearsheimer either must identify the conditions that propel states to maximize relative power or he must make unstated assumptions about state motivations of extreme fear or greed. This problem is not Mearsheimer's alone, however. As argued by various 
critics, structural realists in general have difficulty explaining why states should always heavily discount the future in anarchy without making hidden motivational assumptions of extreme fear since the pressures on survival are not necessarily always equally high (Brooks 1997; Donnelly 2000: Chapter 2).

Second, and closely related to the above, Mearsheimer's thinking suffers from a problem regarding the role of the rationality assumption. As argued by defensive realists (and certainly acknowledged by Mearsheimer), survival-driven states in anarchy are propelled to balance against expansionists because increasingly powerful states constitute a threat to their autonomy. The balancing proposition, however, directly collides with Mearsheimer's power-maximization hypothesis because power maximization makes little sense when it is likely to be met with countervailing balancing coalitions. Thus, a rigid interpretation of the balancing dynamic implies that power maximization is irrational (Wivel 2000: Chapter 3) and Mearsheimer in essence has to violate the rationality assumption. Mearsheimer counters this point in two ways. First, he argues that states only seek hegemony when the benefits outweigh the costs, that is, when the balance of power is so heavily skewed in one state's favour that it becomes a potential hegemon (Mearsheimer 2001c: 37). This is of course a major modifier on offensive state behaviour since it makes aggression less predominant than one would expect. On the other hand, this qualification seems contradictory. If the weak are likely to balance against the strong, the resulting cost-benefit analysis of potential hegemons should rarely result in an outcome favouring expansion.

Second, as argued above, Mearsheimer also points out that balancing is not the automatic 'iron law', which Waltz finds. Rather, Mearsheimer posits that countervailing balances often fail to form because rational states, sensitive to costs, are strongly inclined to buck-pass hoping that somebody else will take the brunt of battle and only tend to balance when they find themselves in the front line. He backs this up with references to the historical record, arguing that aggression seems to succeed about 50 to 60 per cent of the time (Mearsheimer 2001c: 39-40). ${ }^{12}$ This is an important point which is also supported by other realist findings but largely ignored by Waltz (Christensen and Snyder 1990). Thus, if relying on one's allies is not an ironclad life insurance, relying on more relative power for oneself may in the end be the most rational response to life in anarchy.

However, when it comes to the most significant wars of the modern age, hegemonic war has never been successful (Kennedy 1988). Thus, emphasizing the tendency to buck-pass only partly resolves the problem of rationality, since, when potential hegemons arrive at the scene balancing is the more rational choice by all other powers, rendering the quest for hegemony futile. 
Third, an ambiguity exists in Mearsheimer's thinking concerning the level of analysis. While it is evident that Mearsheimer aims at building a general theory in terms of structural system-wide properties, the inclusion of geographic location as an intervening variable implies that regional dynamics, not systemwide ones, become the focal point of his analysis. This begs the question as to whether regions are independent systems with structural dynamics of their own. This seems to be the case. For example, in his Back to the Future article Mearsheimer (1995a: 80, footnote 4) argues that 'polarity arguments can be used to assess the prospects for stability in a particular region, provided that the global and regional balances are distinguished from one another and the analysis is focused on the structure of power in the relevant region.' However, at the same time it is clear that the great powers in different regions also interact across regions in a global balance of power. For instance, the caveat of Mearsheimer's theory is precisely that the great powers keep a close eye on the balance of power - mainly in their own neighbourhood but also in other regions. This is particularly true of regional hegemons that aim to prevent peers from emerging in other regions. For instance, in his 1998 article, The Future of America's Continental Commitment, Mearsheimer finds that a grand strategy of counter-hegemony ${ }^{13}$ best describes the US strategy towards Europe and North-East Asia. Thus, Mearsheimer blurs the regional level and the systemic level of analysis. ${ }^{14}$ This is problematic because we do not know when the regional level or the system-wide level is the main explanatory factor. This renders the theory difficult and perhaps even impossible to call into question on Mearsheimer's own terms. If developments in the regional balance do not explain an empirical event, we have a second chance to verify the theory by looking for system-wide developments and vice versa. Only if the theory fails at both the regional and system-wide level is the theory in serious trouble.

Another problem associated with Mearsheimer's regional analyses is how to define regional boundaries. This is important because the essence of regional security analyses is precisely that some states are included while others are excluded. There is, however, no generally accepted way of defining regions, although some attempts have been made by Buzan (1991), Charles Tilly (1992: Chapter 6) and Buzan and Wæver (2003), for example. Mearsheimer, unfortunately, does not address the problem nor does he attempt to solve it, but simply takes entities like Europe or North-East Asia for granted. Again, this compounds the problem of immunization to disproval since the regions themselves can, in principle, be defined in an ad hoc manner.

Fourth, a problem exists concerning the hierarchy between the two key variables in Mearsheimer's theory: the international distribution of power and location. Mearsheimer does not clearly state which of these variables is the more important. Therefore, both variables can individually account for the empirical outcomes. This is problematic because it may make it too easy to find 
corrobating evidence supporting the theory. Mearsheimer's empirical analyses seem to suffer from this exact weakness. For instance, he argues that the Soviet Union, contrary to his general expectation, did not balance against Nazi Germany in 1939, but buck-passed because a belt of weak Central European states separated the two countries - even though Germany had become a potential hegemon in the late 1930s. However, had the Soviets instead chosen to balance the theory would still be right because Germany, being a potential hegemon, threatened to dominate Europe. The role of geographical location a non-structural variable in Mearsheimer's otherwise super-structural theory - thus brings us back to the problem discussed above regarding the relationship between the levels of analysis. The ambiguous role of location inevitably makes one wonder if the inclusion of geographical location serves as a residual explanation to account for obvious anomalies in the theory, for example why the US and the United Kingdom have mostly pursued defensive strategies and not acted like aggressive power-maximizers. Thus, by not clearly relegating the geographical variable to second place Mearsheimer is able to explain almost everything ex post, risking a grab-bag argument. It should be noted, however, that Mearsheimer's argument compared to virtually all other political science theories is quite sparse in its number of variables. Thus, many students of international politics, realists and non-realists alike, have no problem compounding numerous variables together in the same theories, thereby increasing their chances of getting something right.

\section{The empirical record}

Having dealt with the internal logic, the next question is: How much of the history of international politics can be explained by offensive realism? This is important since a theory's empirical validity determines whether the theory is ultimately persuasive (cf. Walt 1999: 11-13).

Mearsheimer's most extensive empirical analysis is found in The Tragedy of Great Power Politics. In this study, he tests offensive realism against six cases of great power behaviour between 1860 and 1991 (Mearsheimer 2001c: Chapter 6). At first glance, these cases compound the predictions of offensive realism. Analysing the behaviour of Japan (1868-1945), Germany (1862-1945), the Soviet Union (1917-1990) and Italy (1861-1943), Mearsheimer finds that they all strove to maximize their relative power in accordance with the predictions of the theory. Japan pursued hegemony in North-East Asia in tandem with its rising power after the Meiji restoration. After being united under Prussia in the 1860s, Germany also soon embarked on a hegemonic crusade, triggering two world wars in the process, until its ambitions were firmly thwarted in 1945. Likewise, Soviet-Russia emerging victorious from the destruction of World War II rose to become a potential hegemon and attempted to dominate the 
European continent. Finally, following the formation of Italy in 1861, that country became a great power and quickly sought to expand into the Balkans and Africa. To be sure, this is an impressive list of supporting evidence as these states made up half of the great powers between 1861 and 1991. As such, the theory explains at least 50 per cent of the potential cases. However, why were the other four great powers not acting as power-maximizers? Mearsheimer argues that in fact they were - at least where the US and the United Kingdom are concerned, while France and China are left out from the analysis. During the 19th century, the US expanded across North America and became a regional hegemon by 1900. Although Mearsheimer, strangely, does not point to this fact himself, the United Kingdom too was expansionist - for centuries building the largest empire the world has ever seen. However, why did these two states not try to dominate the other great powers, as one would expect from offensive realism? Mearsheimer responds that because both the United Kingdom and the US were separated from Europe and Asia by bodies of water they were unable to project sufficient land power to oust their continental rivals. In accordance with offensive realism, they mainly pursued an offshore balancer strategy of buck-passing towards continental Europe and Asia only sending their troops whenever a potential hegemon emerged (2001c: Chapters 6 and 7).

However, a closer look reveals some problematic inconsistencies. Most importantly, the aggressive behaviour of Japan seems to contradict the theory (Snyder 2002). Being an offshore state Japan was isolated from mainland Asia. According to Mearsheimer's propositions regarding location, Japan should have pursued an offshore balancer strategy. However, Japan pursued a continental-style strategy of aggrandizement - seizing territory in Korea, China and South-East Asia. Thus Japan's behaviour violates the basic predictions of offensive realism. Recognizing this, Mearsheimer counters that Japan was able to expand across the narrow Sea of Japan and acted like a landlocked power because it faced weak opponents. The US and the United Kingdom, on the other hand, were facing a fortified European continent occupied by strong great powers, rendering conquest in mainland Europe impossible (Mearsheimer 2001c: 264-265). This auxiliary explanation, however, reflects the tension discussed above concerning the under-specified relationship between the variables of the theory: When does geography and when does the balance of power explain outcomes?

Two additional problems emerge concerning the empirical record. First, Japan, Germany, Italy and the Soviet Union in the late 19th and the 20th century represent about as aggressive a bunch of great powers as can be imagined (Snyder 2002: 161). This issue raises doubts that Mearsheimer's case selection may have been made on the dependent variable - the weakest criterion of case selection since one risks excluding beforehand the full range of 
possible observations (King et al. 1994: Chapter 4). Had Mearsheimer included Prussia before 1862, France, Austria-Hungary or Russia before World War I, he may have found less clearcut support for his theory. Mearsheimer (2001c: 465 , footnote 2) responds that he has not analysed additional cases due to limitations of space, but is confident that further cases would also support his theory - a curious claim that is not elaborated in any way.

Second, Mearsheimer's interpretation is not entirely convincing as most of the hyper-aggressive continental great powers were also temporarily nonaggressive. After the 1870 Franco-German war, Germany pursued a balancing strategy until the early 20th century. Mearsheimer (2001c: 181) explains that Germany, geographically locked in, lacked the strength until 1903 to take on the other Great Powers - but was nevertheless secretly entertaining aggressive aims all along. Although there may be some truth to this, this ad hoc explanation is problematic because it does not explain why Germany waited until 1914 to wage World War I. Furthermore, Mearsheimer's argument that Germany was secretly entertaining expansionist aims, although not behaving aggressively is problematic because, if maintained, it makes the theory nonfalsifiable. Any non-aggressive state could be said to be temporarily passive waiting for a better time to expand (Snyder 2002: 159-160).

\section{After the Cold War}

Turning to the post-Cold War phase Mearsheimer (1993, 1995a, 2001c: Chapter 10) has on several occasions predicted that tensions and securitycompetition in Europe and North-East Asia will likely increase. These predictions are rooted in the double problems of the return of regional multipolarity and Germany's and China's potential of becoming regional hegemons.

In his article Back to the Future, Mearsheimer (1995a) predicted that Europe, liberated from the bipolar US-Soviet confrontation, would again experience fierce great power competition fuelled by the power and fear of a rising Germany. In addition, Mearsheimer (1995a) finds that Germany - a nonnuclear power and therefore vulnerable to nuclear-armed France and Great Britain - will likely fear encirclement and be likely to pursue a nuclear capacity of its own in the 21 st century and increase the level of tension even more.

More than a decade after the end of the Cold War, these fears, fortunately, seem unfounded. This calls into question the power of offensive realism as an apt explanation of post-Cold War international politics. Despite Germany's rising power, security competition has not re-emerged and the debate on a resurgent Germany seems outdated. In fact, contrary to Mearsheimer's analysis, integration rather than disintegration has characterized European 
politics since the termination of the Cold War. And so far, Germany has not taken steps to build a nuclear deterrent but, in fact, decided to terminate its civilian nuclear industry (Homola 2003). In addition, the enlargement of the EU into Eastern and Central Europe represents an outstanding level of cooperation among the European states - developments that are hard to reconcile with Mearsheimer's propositions. So far, however, Mearsheimer (2001c: Chapter 10) remains confident in his predications, arguing that too little time has passed to test his hypotheses.

In North-East Asia containing the great powers of Russia, Japan and China (the latter having prospects of becoming a potential regional hegemon in Asia and a peer competitor of the US), Mearsheimer (2001c: Chapter 10) has argued in the same vein that tensions are likely to rise. These predictions seem to fare better than in the case of Europe as security competition has indeed been more intense in North-East Asia. On the whole, however, it is hard to recognize the level of conflict expected by Mearsheimer in Asia. Especially China, although increasingly assertive, has kept a fairly low and cooperative profile towards its neighbours and the US. Institutionalized cooperation has also expanded in the region among the major players, for example, in the Shanghai Corporation Organization between China and Russia. And the minor powers in South-East Asia have intensified cooperation among themselves within the Association of Southeast Asian Nations (ASEAN) bloc and expanded the regional dialogue on security in fora like the Asian Regional Forum. So far, Mearsheimer's analysis of post-Cold War international politics seems to be off the mark.

\section{US grand strategy}

Mearsheimer argues that the main factor that has so far prevented the swift reemergence of power competition in Europe and Asia is the continued continental commitment of the US. The US has kept troops in Europe and Asia and this has postponed the unfolding of the above scenarios. At the same time, Mearsheimer does not expect this to last and predicts the US to pull back from Europe and North-East Asia sooner rather than later (Mearsheimer 2001b).

This expectation rests on his claim that the US is a regional hegemon in the Americas. Hence, it cannot extend its position further due to the stopping power of water and therefore it is a rare status quo power (Mearsheimer 2001c: 386-392; Layne 2002). Thus, according to the dictates of offensive realism, the US will soon pursue an offshore balancer strategy (Mearsheimer 1998, 2001b), re-committing itself to the continent only if potential hegemons should emerge.

This prediction, however, stands in contrast to most US grand strategic behaviour in the past 15 years. Far from ending its continental commitment, the US has initiated a global policy of 'engagement and enlargement' (Hansen 
2000b: Chapter 5) that has included the expansion of the North Atlantic Treaty Organization (NATO), a global war against terrorism after the 11 September attacks in 2001 (occupying Afghanistan in the process) and the conquering of Iraq in the spring of 2003. Moreover, the US has not been content with relying on its nuclear second-strike capability but accelerated efforts to develop a missile defense system. Although an operational system is years away (Stout and Cushman 2004), this is certainly a first step in changing the world's nuclear balance that could edge the US closer to a nuclear monopoly and to becoming a global hegemon.

These developments indicate a power-maximizing strategy rather than offshore balancing (Layne 2002). Oddly, although the US seems to be determined on increasing its relative power still further, this behaviour not only contradicts offensive realism but also exposes a curious tension in Mearsheimer's thinking, that is, a tension between the expectation of US self-restraint that would have been in perfect accordance with his defensive realist target and his general power-maximization argument.

One reason why Mearsheimer seems to be off the mark regarding US grand strategy may simply be due to the fact that structural theories are not deterministic. According to Waltz (1979: 76-77), statesmen can take whatever action they want, but if they ignore the structural incentives they will eventually be punished and 'fall by the wayside.' Thus, it is not necessarily Mearsheimer's theory that is wrong, rather it is American policies.

Another and more profound reason could be Mearsheimer's denial of unipolarity, that is, an international distribution of power with only one great power (Wohlforth 1999; Hansen 2000b; Layne 2002: 122-125). Arguably, unipolarity, like multi- and bipolarity inheres distinctive dynamics in terms of proneness to war and alignment opportunities (e.g. Hansen 2000a) that simply eludes Mearsheimer's analysis, which only takes into account multipolar and bipolar systems. On the other hand, as is clear from the ongoing debate among scholars endorsing unipolarity, the specific unipolar incentives upon US strategy are unclear since an unrestrained power has a wide choice between pursuing an aggressive grand strategy of global hegemony or a more selfrestrained strategy of preponderance, that is, keeping its relative lead. ${ }^{15}$

Surely, from a robust offensive realism it would be only logical to expect a unipolar US strategy of global hegemony (Layne 2002). However, Mearsheimer maintains that the present system is not unipolar ${ }^{16}$ (resembling what Mearsheimer terms global hegemony), and this stance flows directly from his geopolitical argument (the stopping power of water prevents unipolarity). ${ }^{17}$ Thus, the US remains a regional hegemon in Mearsheimer's scheme (Layne 2002: 124-125) and because of this Mearsheimer has to brand America as an off-shore status quo power. In view of America's grand strategic behaviour, however, this position appears progressively untenable and questions whether 
the stopping power of water is really such an obstacle since a great power with beachheads on a continent and a strong navy to support its forces seems to be able to overcome the stopping power of water quite easily (Layne 2002). Thus, once again the geographical variable seems to be the weak point in Mearsheimer's theory. On the one hand, it is the very inclusion of geography that enables him to explain why the US and the UK have not historically behaved like power-maximizers. Yet, the stopping power of water argument now seems to prevent offensive realism from capturing the essence of current American foreign policy behaviour. This said, it might be too early to call the curtain on Mearsheimer's post-Cold War predictions. For instance, the present US administration has announced plans to cut and relocate its troops in Europe (Saradzhyan 2003; Bumiller and Shanker 2004; Lander 2004) and similar actions may be true of the US military presence in Korea (Shanker 2004).

\section{Mearsheimer and US foreign policy}

In light of the above contradictions between actual American foreign policy and the predictions of offensive realism Mearsheimer has, not surprisingly, been an ardent critic of America's post-Cold War strategy. According to Mearsheimer, the real challenge for US survival is China. Despite currently being militarily weak and economically inferior, China is likely to rise and if that happens it will inevitably seek to expel the US from its backyard and establish itself as the dominant great power in Asia, making life difficult for America. Thus, instead of wasting time and money on foreign policy follies overseas, the US should, according to Mearsheimer, concentrate on slowing the rise of China rather than stimulating it through the hitherto accommodating economic policies (Mearsheimer 2001c: Chapter 10; Brzezinski and Mearsheimer 2005).

In accordance with this, Mearsheimer has been one of the strongest critics of the US campaign against Iraq in 2002/03, arguing that the alleged Iraqi weapons of mass destruction (WMD) did not pose a threat due to America's overwhelming deterrent capability (Mearsheimer and Walt 2003a, b). If indeed Saddam Hussein did possess WMD, he would be easily deterred and an offshore balancing strategy relying on Iran was the proper answer to curb Iraqi ambitions (Mearsheimer 2002).

Mearsheimer has also waged fierce criticisms against the way Washington has conducted the war against terrorism. Even though offensive realism has little to say about the causes of terrorism (states are the only significant actors), Mearsheimer does have something to say about the proper response. According to Mearsheimer, the US should not squander resources on largescale military operations against countries such as Afghanistan that pose little 
threat. However, more interestingly, he also finds that military might is unlikely to bring victory in a war against terror. Rather, it aggravates the problem as its increases hostility in the Islamic world - the key breeding ground for terrorist organizations. What the US needs to do is rely on intelligence and small-scale military operations to root out the terrorists and, importantly, try to win 'the hearts and minds' of hostile peoples in order to reduce terrorist recruitment. Unsurprisingly, this is, done best by pursuing an offshore balancer strategy toward the Islamic world - toning down America's military presence in that region, which would also help improve the country's image around the world (Mearsheimer 2001a, 2002).

However, once again, the latter foreign policy advice reveals an interesting contradiction in Mearsheimer's thinking. On the one hand, he argues that great powers strive (with good reason) to oust their great power rivals without much regard to the formation of countervailing coalitions. However, when it comes to terrorism the US, recognizing that an aggressive strategy will breed increased hostility, should pursue a more accommodating approach. This raises the question of the role of perceptions of intent, something which Mearsheimer does not address at all but which other realists have stressed (e.g. Walt 1990, 1996). However, if perceptions play a role in the formation of countervailing coalitions is power maximization or restraint the best route to survival?

In sum, although Mearsheimer's policy advice was undoubtedly correct in most people's view today, US foreign policy seems not to conform to the dictates of offensive realism and anomalies inherent in Mearsheimer's theoretical construct are mounting by the day. Although Mearsheimer's theory seems to give a reasonably exact account of great power behaviour before 1991, it seems to be quite far off the mark regarding post-Cold War great power politics and US grand strategy. This is not entirely invalidating, however, because the available empirical record only covers little more than a decade - a short time span in terms of structural theory.

\section{Is Offensive Realism at a Dead End?}

Mearsheimer's analyses encounter empirical anomalies after the Cold War and are built on a not entirely flawless logic. Does this spell the end of offensive realism? I think not. As argued by King, Keohane and Verba (1994: 101), 'the question is less whether, in some general sense, a theory is false or not' since 'virtually every interesting social science theory has at least one observable implication that appears wrong'. The defining question is 'how much of the world the theory can help us explain'. Furthermore, compared to most other IR theories offensive realism does pretty well. And, although Mearsheimer fails 
to explain post-Cold War world politics, we have to wait a couple of decades to conclude whether events will conform to the theory's predictions. So, in the meantime what can we use Mearsheimer's insights for?

First, offensive realism may be used in further refining structural realism. Mearsheimer solves a theoretical puzzle that has marred structural defensive realism, that is, how can we from the structural level explain the sheer amount of international conflict throughout modern history (cf. Zakaria 1995; Schweller 1996; Labs 1997). Especially, as asked by Jack Snyder (1991), why have a number of great powers 'over-expanded' when the system induces them to be defensive positionalists?

Mearsheimer offers a solution that, contrary to Snyder, does not look to the domestic level and brings structural realism back to the defunct reductionist realism of the 'evil school'. Rather, Mearsheimer's big innovation is his point that defensive realists like Waltz have gotten the impact of structure wrong. Arguably, since balancing often fails and, hence, is not the ironclad life insurance Waltz thought it to be, the international system structure can also generate incentives for power maximization. Thus, by 'bringing the revisionist state back in' Mearsheimer takes on the challenge posed by Randall Schweller's (1996) charge that structural realism suffers from an invalidating status quo bias since it fails to take account of the conflict generating role of revisionist states. Indeed, in Mearsheimer's scheme all states are revisionist (cf. Snyder 2002; Schmidt 2004).

In addition, although Mearsheimer needs to clarify the hierarchy between his two explanatory variables of power and geography, the inclusion of unit-level variables such as location increases the relevance of structural realism because it enhances its ability to generate specific hypotheses about state behaviour. From offensive realism we may deduce hypotheses about when specific states are likely to balance, buck-pass or wage hegemonic war. This is a major advance compared to Waltz's version, from which we can only generate extremely general hypotheses about international outcomes that are difficult, if not impossible to test empirically (Tellis 1996; Schweller 1998; Wivel 2000).

However, most importantly, Mearsheimer's self-conscious and explicit theoretical design improves the potential of the realist research program because it facilitates the identification of different theoretical positions within the tradition (cf: Taliaferro 2001). This both facilitates the task of weeding out the theories with the least explanatory power and highlights openings for a possible fusion of offensive and defensive realism. By emphasizing that states are sometimes acting as defensive positionalists and at other times as offensive power-maximizers, Mearsheimer opens the door to a possible merger between offensive and defensive realism. Against this positive assessment, however, could be charged that by showing that the international structure both provides incentives for defensive and aggressive state behaviour Mearsheimer 
does not open for a structural realist merger at all but merely demonstrates that international structure has no specific effects whatsoever, thus annulling structural realist insights altogether. ${ }^{18}$

This critique has some truth to it. However, it ignores the fact that the historical record demonstrates that the level of aggression varies greatly across time and space and, as Mearsheimer (2001c: Chapter 9) himself forcefully shows, times of unbalanced multipolarity seem to generate high levels of conflict, while bipolar periods seem to experience a much lower likelihood of conflict. This points to the possibility that state behaviour is largely affected by the probability of conflict (cf. Brooks 1997). Thus, a merger between offensive and defensive realism might be successful by introducing the likelihood of conflict as an intermediary variable, thus, making more specific predictions as to when states tend to act as defensive positionalists and power-maximizers. The logic behind this argument is that the higher the likelihood of conflict the greater is the likelihood of aggressive power-maximizing state behaviour because as the likelihood of conflict increases so does the premium, which states must place on survival and the distribution of relative gains. On the other hand, if the likelihood of conflict is low states can afford to be less concerned with relative gains since their survival is not in immediate danger and they can afford to be satisfied with the status quo (Wivel 2000). Testing the effects of moderating unit-level variables upon the probability of conflict is one way to reach a more complete realist theory (Brooks 1997; Wivel 2000; Taliaferro 2001). However, contemporary realists often overlook the fact that structural theory already inheres different probabilities of conflict in terms of different polarities. Arguably, the probability of conflict is high in multipolar systems due to shaky alliances and diffuse power-relations. And it is in multipolar systems that we can historically observe the highest frequency of powermaximizing behaviour. Conversely, bipolar systems produce lower probabilities of conflict and balancing, rather than power maximization, seems to be more predominant in such systems (Waltz 1964). Thus, a first step forward for a more complete realist theory would be to investigate the effects of different polarities on the probability of conflict and its impact upon state behaviour.

Finally, we can use Mearsheimer's insights to conduct further research on the history of great power politics. Although Mearsheimer covers major chunks of modern history, he has not tested his theory against the era from the founding of the modern state system in 1648 until the Napoleonic Wars. Similarly, the period of the European Concert from 1815 until the Crimean war is left largely untouched. Moreover, we should use Mearsheimer's analyses in the coming years to continually test his theoretical propositions against contemporary world politics. Owing to the dominant position of the US, figuring out whether Washington in the end opts for a strategy of offshore balancing or primacy is of the utmost importance for decision makers around 
the world and hence whether offensive realism provides a sound guide to foreign policy.

\section{Conclusion}

This article indicates that Mearsheimer's work constitutes an important addition to Kenneth Waltz's structural realism. Arguing that the logic of anarchy is consistent with expansionist state behaviour Mearsheimer's core theory of offensive realism solves hitherto unsolved anomalies in defensive structural realism such as why a number of great powers have sought hegemony and why conflict is so frequent between states, which is hard for defensive realists to explain. In the process, Mearsheimer also makes important contributions to alliance theory and foreign policy theory, and offers new insights into the role of power and geography in world politics. However, some blemishes remain. Most importantly, the internal logic of offensive realism is not without problems and the theory encounters anomalies when confronted with the empirical record - especially in the post-Cold War phase. This said, there is little doubt that Mearsheimer's contribution is an improvement to structural realism and lights the way toward a more complete structural realist theory that can more accurately account for both defensive and offensive state behaviour. Thus, Mearsheimer's work is likely to rank among the most important advances in modern realism.

\section{Notes}

1 I would like to thank Anders Wivel, the editors of the Journal of International Relations and Development, Stefano Guzzini and Milan Brglez, and three anonymous reviewers for their careful and helpful comments.

2 Mearsheimer's Back to the Future (1995a) and The False Promise (1995b) articles spurred major debates and The Tragedy of Great Power Politics (2001c) has generated an avalanche of review articles - see, for example, Layne (2002), Lynn-Jones (2002), Rosecrance (2002), Snyder (2002), Walton (2002), Hendrickson (2003), Hyer (2003), Lee (2003), Schmidt (2004) and Shore (2005). In addition, Mearsheimer's criticism of America's anti-terror war and the 2003 war against Iraq has spurred debate - see Mearsheimer (2001a, 2002), Mearsheimer and Walt (2003a,b), Bastarache (2004) and Bishai (2004).

3 Since I focus rather narrowly on Mearsheimer's additions to Waltzian structural realism and later developments of this strand such as post-classical realism and neoclassical realism, the scope of the article is rather limited. Thus, the article cannot tell us much about the broader implications of Mearsheimer's theoretical thinking vis-à-vis the wider realist tradition. It can, however, serve as a useful starting point for such a wider theoretical appraisal.

4 For a brief discussion of the realist core assumptions, see, for example, Brown et al. (1995), Spirtas (1996), Legro and Moravcsik (1999), McFarlaine (1999), Taliaferro (2001) and Schweller (2003: 322-329).

5 Mearsheimer's concept of polarity is roughly in accordance with Waltz's (1979) arguing that multipolarity - an international power distribution containing more than two great powers - 
is more war prone than bipolar ones - a power distribution containing two great powers. Unlike Waltz, however, Mearsheimer posits that multipolar systems can be balanced or unbalanced. Balanced multipolarity describes a roughly equal distribution of power among the great powers. In unbalanced multipolar system the balance is heavily asymmetrical in favour of one of the great powers. This great power is able to make a run for regional domination making it a potential hegemon.

6 Although Waltz did not outright deny the importance of unit-level variables (Waltz 1979: 40), he wanted to remedy the reductionist failure of earlier realist thought by taking into account the effects of international structure (Waltz 1979: Chapters 2-4, 1990). In order to do so, Waltz isolated the effects of structure and left other variables out. For a thorough discussion of Waltz's structure-unit distinction, see Buzan et al. (1993: Chapter 3).

7 See, for example, Stephen Walt $(1990,1996)$ and Wivel (2000).

8 Waltz's distinction between theories of foreign policy and international politics has been much criticized. For example, in a 1996 article, Colin Elman has forcefully argued that nothing hinders the construction of neorealist theories of foreign policy (1996) and others (e.g. Mouritzen 1997) have pointed out that a theory of international politics cannot be clearly distinguished from a theory of foreign policy since it will have implications for foreign policy as well. However, Waltz (1996) has fiercely defended his position. See also Schweller (2003: 320-322).

9 See, for example, Walt (1990, 1996), Rose (1998), Schweller (1998), Zakaria (1998) and Taliaferro (2001).

10 For accounts of the intra-realist debate, see Brown et al. (1995), Spirtas (1996), Brooks (1997), Rose (1998), Jervis (1999), Taliaferro (2001), Walt (2002b) and Wivel (2002).

11 On this point, see also Christensen and Snyder (1990), and Snyder (1997).

12 However, the few specific cases mentioned are curious since they concern only minor acts of aggression not likely to shift the balance of power such as Germany's acquisition of SchleswiegHolstein in 1864.

13 Counter-hegemony is defined as a strategy based on the belief that established regional hegemons are principally concerned that no other great power dominate any region of the world (Mearsheimer 1998).

14 For an attempt to solve this problem see Elman (2004).

15 See, for example, Waltz (1993, 1995), Brzezinski (1997), Kupchan (1998), Bell (1999), Huntington (1999), Layne (2000), Walt (2002a), Krauthammer (2002), Hansen (2003) and Posen (2003)

16 To be sure, although unipolarity now seems to be generally accepted, a number of scholars do not endorse the concept without qualification (e.g. Huntington 1999; Schweller 1999; Buzan and Wæver 2003: 30-33).

17 Mearsheimer's rejection of unipolarity may also stem from the more profound reason that a unipolar structure is a non-balance of power system - at least among great powers. Thus, accepting unipolarity challenges the fundamental thrust of structural realist analysis with its emphasis on anarchy and the balance of power as the driving force of world politics. I thank an anonymous referee for this point.

18 I thank the editors of the Journal of International Relations, Stefano Guzzini and Milan Brglez for making me aware of this point.

\section{References}

Bastarache, Lisa (2004) 'American Amnesia Interviews John Mearsheimer', American Amnesia (22 December): available at http://www.int.amnesia.com/ mearsheimer-1.htm (15 July, 2005).

Bell, Coral (1999) 'American Ascendancy and the Promise of Concert', The National Interest 57(Fall): 55-63. 
Bishai, Linda S. (2004) 'Liberal Empire', Journal of International Relations and Development 7(1): 48-72.

Brooks, Stephen G. (1997) 'Dueling Realisms', International Organization 51(3): 445-77.

Brown, Michael E., Sean M. Lynn-Jones and Steven E. Miller, eds (1995) The Perils of Anarchy: Contemporary Realism and International Security, Cambridge, MA: MIT Press.

Brzezinski, Zbigniew (1997) The Grand Chessboard: American Primacy and its Geostrategic Imperatives, New York: Basic Books.

Brzezinski, Zbigniew and John J. Mearsheimer (2005) 'Clash of the Titans', Foreign Policy 146(January/February): 46-51.

Bumiller, Elisabeth and Thom Shanker (2004) 'Bush Tells Veterans of Plan to Redeploy G.I.'s Worldwide', The New York Times (17 August): A6.

Buzan, Barry (1991) People, States, and Fear, (2nd edn), New York: Harvester Wheatsheaf.

Buzan, Barry, Charles Jones and Richard Little (1993) The Logic of Anarchy: Neorealism to Structural Realism, New York: Columbia University Press.

Buzan, Barry and Ole Wæver (2003) Regions and Powers: The Structure of International Security, Cambridge: Cambridge University Press.

Carr, Edward Hallet (1946/1974) The twenty years' crisis, 1919-1939: An Introduction to the Study of International Relations, London: St. Martin's Press.

Christensen, Thomas and Jack Snyder (1990) 'Chain Gangs and Passed Bucks: Predicting Alliances under Multipolarity', International Organization 44(2): 137-68.

Copeland, Dale (2000) The Origins of Major War, Ithaca, NY: Cornell University Press.

Donnelly, Jack (2000) Realism and International Relations, Cambridge: Cambridge University Press.

Elman, Colin (1996) 'Horses for Courses: Why not Neorealist Theories of Foreign Policy?' Security Studies 6(1): 7-53.

Elman, Colin (2004) 'Extending Offensive Realism: The Louisiana Purchase and America's Rise to Regional Hegemony', American Political Science Review 98(4): 563-76.

Grieco, Joseph (1993) Co-operation among Nations, Ithaca, NY: Cornell University Press.

Hansen, Birthe (2000a) 'The Unipolar World Order', in Birthe Hansen and Bertel Heurlin, eds, The New World Order, 112-33, London: Macmillan.

Hansen, Birthe (2000b) Unipolarity and the Middle East, Richmond, VA: Curzon Press.

Hansen, Birthe (2003) Overmagt: USA og Europa i det 21. århundrede, København: Gyldendal.

Haslam, Jonathan (2002) No Virtue Like Necessity: Realist Thought in International Relations Since Machiavelli, New Haven, CT: Yale University Press.

Hendrickson, David C (2003) 'The Tragedy of Great Power Politics', World Policy Journal 20(1): 93-102.

Homola, Victor (2003) 'Germany: First Nuclear Plant Shut', The New York Times (15 November): A5.

Huntington, Samuel (1999) 'The Lonely Superpower', Foreign Affairs 78(2): 35-49.

Hyer, Eric (2003) 'The Tragedy of Great Power Politics - Mearsheimer's Neorealist Predictions: The Haunting Specter of China as a Great Power', Issues and Studies 39(2): 225-32.

Jervis, Robert (1999) 'Realism, Neoliberalism, and Cooperation: Understanding the Debate', International Security 24(1): 42-63.

Kennan, George (1946) 'Kennan's Long Telegram: The Chargé in the Soviet Union (Kennan) to the Secretary of State, $861.00 / 2$ - 2246', available at http://www.gwu.edu/ nsarchiv/coldwar/ documents/episode-1/kennan.htm (15 July, 2005).

Kennedy, Paul (1988) The Rise and Fall of the Great Powers: Economic Change and Conflict from 1500 to 2000, London: Fontana Press.

King, Gary, Robert Keohane and Sydney Verba (1994) Designing Social Inquiry: Scientific Inference in Qualitative Research, Princeton, NJ: Princeton University Press. 
Kissinger, Henry (1964) A World Restored, New York: Grosset and Dunlap.

Krauthammer, Charles (2002) 'The Unipolar Moment Revisited', The National Interest 70(Winter): 5-20.

Kupchan, Charles (1998) 'After Pax Americana: Benign Power, Regional Integration, and the Sources of Stable Multipolarity', International Security 23(2): 40-79.

Labs, Eric (1997) 'Beyond Victory: Offensive Realism and the Expansion of War Aims', Security Studies 6(4): 1-49.

Lander, Mark (2004) 'Proposed US Base Closings Send a Shiver Through a German Town', The New York Times (22 August), Section 1: 8.

Layne, Christopher (2000) 'From Preponderance to Offshore Balancing', in Michael E. Brown, Owen R. Coté Jr., Sean M. Lynn-Jones and Steven E. Miller, eds, Amerca's Strategic Choices, 99-137, Cambridge, MA: MIT Press.

Layne, Christopher (2002) 'The Poster Child for Offensive Realism: America as a Global Hegemon', Security Studies 12(2): 120-63.

Lee, Gerald Geunwook (2003) 'To Be Long or Not to Be Long — That Is the Question: The Contradiction of Time-Horizon in Offensive Realism', Security Studies 12(2): 196-217.

Legro, Jeffrey W. and Andrew Moravcsik (1999) 'Is Anybody Still a Realist?' International Security 24(2): 5-55.

Lynn-Jones, Sean M. (2002) 'The Tragedy of Great Power Politics - Review Essay', International Affairs 78(2): 365-6.

McFarlaine, Neil (1999) 'Realism and Russian Strategy after the Collapse of the USSR', in Ethan B. Kapstein and Michael Mastanduno, eds, Unipolar Politics: Realism and State Strategies after the Cold War, 218-60, New York: Columbia University Press.

Mearsheimer, John J. (1983) Conventional Deterrence, Ithaca, NY: Cornell University Press.

Mearsheimer, John J. (1984) 'Nuclear Weapons and Deterrence in Europe', International Security 9(3): 19-46.

Mearsheimer, John J. (1988) Lidell Hart and the Weight of History, London: Brassey's Defense Publishers.

Mearsheimer, John J. (1989) 'Assessing the Conventional Balancee: The 3:1 Rule and its Critics', International Security 13(4): 54-89.

Mearsheimer, John J. (1993) 'The Case for a Ukrainian Deterrent', Foreign Affairs 72(3): 50-66.

Mearsheimer, John J. (1995a) 'Back to the Future: Instability in Europe after the Cold War', in Michael E. Brown, Sean M. Lynn-Jones and Steven E. Miller, eds, The Perils of Anarchy, 78-129, Cambridge, MA: MIT Press.

Mearsheimer, John J. (1995b) 'The False Promise of Institutional Institutions', in Michael E. Brown, Sean M. Lynn-Jones and Steven E. Miller, eds, The Perils of Anarchy, 332-76, Cambridge, MA: MIT Press.

Mearsheimer, John J. (1998) 'The Future of America's Continental Commitment', in Geir Lundestad, ed., No End To Alliance, 221-42, London: Macmillan.

Mearsheimer, John J. (2001a) 'Guns Won't Win the Afghan War', The New York Times (4 November), Section 4: 13.

Mearsheimer, John J. (2001b) 'The Future of the American Pacifier', Foreign Affairs 80(5): 46-61.

Mearsheimer, John J. (2001c) The Tragedy of Great Power Politics, New York: Norton.

Mearsheimer, John J. (2002) 'Hearts and Minds', The National Interest 69(Fall): 13-6.

Mearsheimer, John J. and Stephen Walt (2003a) 'Keeping Saddam in his Box', The New York Times (2 February), Section 4: 15.

Mearsheimer, John J. and Stephen Walt (2003b) 'An Unnecessary War', Foreign Policy 134(January/February): 51-9.

Morgenthau, Hans J. (1948/1985) Politics Among Nations, New York: Alfred A. Knopf. 
Mouritzen, Hans (1997) 'Kenneth Waltz: A Critical Rationalist between International Politics and Foreign Policy', in Ole Wæver and Iver B. Neumann, eds, The Future of International Relations: Masters in the Making?, 66-89, London and New York: Routledge.

Niebuhr, Reinholdt (1932/2001) Moral Man and Immoral Society: A Study in Ethics and Politics, Louisville, KY: Westminster John Knox Press.

Posen, Barry (2003) 'Command of the Commons', International Security 28(1): 5-46.

Rose, Gideon (1998) 'Neoclassical Theories of Foreign Policy', World Politics 51(1): 144-73.

Rosecrance, Richard N (2002) 'War and Peace', World Politics 55(1): 137-55.

Saradzhyan, Simon (2003) 'Washington Tells Moscow It's Moving East', The Moscow Times (11 December): 1.

Schmidt, Brian C. (2004) 'Realism as Tragedy', Review of International Studies 30(3): 427-41.

Schweller, Randall (1996) 'Neorealism's Status Quo Bias: What Security Dilemma?' Security Studies 5(3): 90-121.

Schweller, Randall (1998) Deadly Imbalances: Tripolarity and Hitler's Strategy for World Conquest, New York: Columbia University Press.

Schweller, Randall (1999) 'Realism and the Present Great Power System: Growth and Positional Conflict over Scarce Resources', in Ethan B. Kapstein and Michael Mastanduno, eds, Unipolar Politics: Realism and State Strategies after the Cold War, 28-57, New York: Columbia University Press.

Schweller, Randall (2003) 'The Progressiveness of Neoclassical Realism', in Colin Elman and Miriam Fendius Elman, eds, Progress in International Relations Theory: Appraising the Field, 311-48, Cambridge, MA: MIT Press.

Shanker, Thom (2004) 'In Agreement with South Korea, US to Move Troops from Seoul', The New York Times (24 July): A4.

Shore, Zachary (2005) 'Three Faces of Realism', Orbis 47(2): 349-59.

Snyder, Glenn (1997) Alliance Politics, Ithaca, NY: Cornell University Press.

Snyder, Glenn (2002) 'Mearsheimer's World: Offensive Realism and the Struggle for Security', International Security 27(1): 149-73.

Snyder, Jack (1991) Myth of Empire: Domestic Politics and International Ambition, Ithaca, NY: Cornell University Press.

Spirtas, Michael (1996) 'A House Divided: Tragedy and Evil in Realist Theory', in Benjamin Frankel, ed., Realism: Restatements and Renewal, 385-424, London: Frank Cass.

Stout, David and John H. Cushman Jr. (2004) 'Defense Missile for U.S. System Fails to Launch', The New York Times (16 December): A1.

Taliaferro, Jeffrey (2001) 'Security Seeking under Anarchy: Defensive Realism Revisited', International Security 25(3): 128-61.

Tellis, Ashley (1996) 'Reconstructing Realism: The Long March to Scientific Theory', in Benjamin Frankel, ed., Roots of Realism, 3-104, London: Frank Cass.

Tilly, Charles (1992) Coercion, Capital, and the European State System 990-1992, Malden, MA: Blackwell.

Van Evera, Stephen (1999) The Causes of War: Power and the Roots of Conflict, Ithaca, NY: Cornell University Press.

Walt, Stephen (1990) The Origins of Alliances, Ithaca, NY: Cornell University Press.

Walt, Stephen (1996) Revolution and War, Ithaca, NY: Cornell University Press.

Walt, Stephen (1999) 'Rigor or Rigor Mortis: Rational Choice and Security Studies', International Security 23(4): 5-48.

Walt, Stephen (2002a) 'American Primacy', Naval War College Review 55(2): 9-28.

Walt, Stephen (2002b) 'The Enduring Relevance of the Realist Tradition', in Ira Katznelson and Helen Milner, eds, Political Science: State of the Art of the Discipline, 197-234, New York: W.W. Norton. 
Walton, Dale C. (2002) 'Coping with Anarchy: Interstate Violence and the Character of American Foreign Policy', Comparative Strategy 21(5): 417-27.

Waltz, Kenneth (1964) 'The Stability of the Bipolar World', Daedalus 93(3): 881-909.

Waltz, Kenneth (1979) Theory of International Politics, New York: Random House.

Waltz, Kenneth (1990) 'Realist Thought and Neorelist Theory', Journal of International Affairs 44(1): $21-37$.

Waltz, Kenneth (1993) 'The New World Order', Millennium: Journal of International Studies 22(2): $187-95$.

Waltz, Kenneth (1995) 'The Emerging Structure of International Politics', in Sean M. Lynn-Jones, Michael E. Brown and Steven E. Miller, eds, The Perils of Anarchy: Contemporary Realism and International Security, 42-77, Cambridge, MA: MIT Press.

Waltz, Kenneth (1996) 'International Politics is Not Foreign Policy', Security Studies 6(1): 54-7.

Wivel, Anders (2000) The Integration Spiral, Ph.D. Dissertation, Copenhagen: University of Copenhagen, Department of Political Science.

Wivel, Anders (2002) 'Realism and Neorealism', in Kerstin Imbusch and Klaus Segbers, eds, IR Online - e-Learning for World Politics, Berlin: Freie Universität Berlin.

Wohlforth, William C. (1999) 'The Stability of a Unipolar World', International Security 24(1): 5-41.

Zakaria, Fareed (1995) 'Realism and Domestic Politics', in Michael E. Brown, Sean M. Lynn-Jones and Steven E. Miller, eds, The Perils of Anarchy: Contemporary Realism and International Security, 462-83, Cambridge, MA: MIT Press.

Zakaria, Fareed (1998) From Wealth to Power: The Unusual Origin of America's World Role, Princeton, NJ: Princeton University Press.

\section{About the Author}

Peter Toft is a Ph.D. fellow at the University of Copenhagen and has been affiliated with Columbia University as a Fulbright and Sasakawa visiting scholar. The Danish Social Science Research Council funds his Ph.D. project as part of the research project 'Lost Power: The American World Order and the Politics of Adaptation'. His research interests are mainly focused on international security and foreign politics, and realist international relations theory. 